Casella, L.L.C Unidades de Conservação e turismo: uma oportunidade para as áreas do entorno. Anais do VIII Congresso Nacional de Ecoturismo e do IV Encontro Interdisciplinar de Ecoturismo em Unidades de Conservação. Revista Brasileira de Ecoturismo, São Paulo, v.4, n.4, 2011, p. 573.

\title{
UNIDADES DE CONSERVAÇÃO E TURISMO: UMA OPORTUNIDADE PARA AS ÁREAS DO ENTORNO
}

\author{
Luana Lacaze Camargo Casella* \\ *Universidade Nove de Julho \\ E-mail: Icasella@uninove.br
}

O ecoturismo nos parques, uma das categorias de unidades de conservação - UC, além de ser um forte aliado para sua conservação e preservação, ao ser incorporado na oferta turística do seu entorno, quando não é o motivador da viagem, proporciona novas oportunidades de atividades aos turistas, estimulando uma maior permanência na localidade, podendo atrair novos segmentos turísticos. Também favorece a geração de renda e emprego nessas áreas que devem fornecer todos os serviços de apoio a estes turistas, como meios de hospedagem, alimentação, transporte, entre outros, no antes e no pós visita, já que muitas destas atividades são inapropriadas ou mesmo proibidas nas UC. Desta maneira, o ecoturismo é capaz de gerar benefícios socioambientais não somente para os turistas, mas também para a população local do entorno da UC. No presente trabalho o objetivo foi identificar o conhecimento dos turistas de Itanhaém e Guarujá sobre o Parque Estadual da Serra do Mar-PESM e qual seria a aceitação, pelos mesmos, quanto à incorporação desta UC na oferta turística local. Isso porque tanto o Guarujá como Itanhaém, estâncias balneárias, tem no turismo uma das mais importantes fontes econômicas municipais, principalmente no segmento de sol e praia, o que confere um caráter sazonal à atividade turística. Entretanto, ambos os municípios estão muito próximos ao PESM, que nos seus mais de 300 mil hectares contém a maior área contínua de Mata Atlântica preservada no Brasil (IF, 2010), o que seria de grande interesse ao desenvolvimento do ecoturismo. Para tanto, em janeiro de 2010, nas praias dos Sonhos e do Tombo, em Itanhaém e Guarujá, respectivamente, aplicou-se, em cada praia, 30 questionários, com 14 questões cada, entre abertas e fechadas, cujo objetivo foi identificar o perfil dos turistas, seus conhecimentos sobre UC e a existência do PESM, bem como identificar, nos visitantes, se há motivações e quais são elas para conhecerem uma UC. Como as entrevistas ocorreram na alta temporada de verão, a maior parte dos entrevistados, em ambas as praias, eram provenientes principalmente da capital São Paulo, o que conferiu uma forte proximidade em todas as respostas obtidas. Os turistas tinham como as principais motivações da viagem o descanso, seguido da busca por um lazer diferente da rotina. Durante sua estada nas duas cidades, a maioria dos entrevistados vai à praia, dando a entender que é a única atividade realizada nas cidades. Observou-se que embora os turistas não saibam o que seja uma UC e da existência do PESM, gostariam de conhecer e se sentiriam estimulados a freqüentá-los, até em outras épocas do ano, simplesmente se houvesse maior divulgação. Para isso, é importante uma boa infra-estrutura e atividades condizentes com as diretrizes do seu plano de manejo, além de um planejamento, desenvolvimento e operação do turismo sustentável integrado com planos de desenvolvimento regional ou nacional, envolvendo o poder público, privado e a sociedade.

Palavras-chave: Unidade de Conservação; Ecoturismo; Parque Estadual da Serra do Mar. 